\title{
Molecular Mapping of a Leaf Rust Resistance Gene on the Short Arm of Chromosome 6B of Durum Wheat
}

\author{
S. A. Herrera-Foessel, Department of Forest Mycology and Pathology, Swedish University of Agricultural Sciences \\ (SLU), Box 7026, S 75007 Uppsala, Sweden; R. P. Singh, International Maize and Wheat Improvement Center \\ (CIMMYT), Apdo. Postal 6-641, 06600 Mexico, D.F., Mexico; J. Huerta-Espino, Campo Experimental Valle de \\ México INIFAP, Apdo. Postal 10, 56230, Chapingo, Edo de Mexico, Mexico; H. M. William, CIMMYT, Mexico; \\ and A. Djurle and J. Yuen, Department of Forest Mycology and Pathology, SLU, Sweden
}

\begin{abstract}
Herrera-Foessel, S. A., Singh, R. P., Huerta-Espino, J., William, H. M., Djurle, A., and Yuen, J. 2008. Molecular mapping of a leaf rust resistance gene on the short arm of chromosome 6B of durum wheat. Plant Dis. 92:1650-1654.

Leaf rust, caused by Puccinia triticina, is an important disease of durum wheat (Triticum turgidum subsp. durum) worldwide, and the most effective way to control it is through the use of resistant cultivars. A partially dominant leaf rust resistance gene present in the International Maize and Wheat Improvement Center-derived Chilean cv. Guayacan INIA and its sister line Guayacan 2 was mapped to chromosome arm 6BS by identifying linked amplified fragment length polymorphisms (AFLPs) and mapping two of the molecular markers in common wheat (T. aestivum) linkage maps of the International Triticeae Mapping Initiative and Oligoculm $\times$ Fukuho-komugi populations. Comparison of infection type responses of the two resistant durums with common wheat testers carrying the previously mapped resistance genes Lr36 and Lr53 on 6BS, and their chromosomal positions, indicated that the resistance gene in durum wheat Guayacan INIA is a new leaf rust resistance gene, which was designated as Lr61. Gene Lr61 is effective against the $P$. triticina race $\mathrm{BBG} / \mathrm{BN}$ predominant in northwestern Mexico and other races infecting durum wheat in various countries.
\end{abstract}

Additional keywords: bulked segregant analysis

Leaf rust, caused by Puccinia triticina, has become an important disease of durum wheat (Triticum turgidum subsp. durum) in Mexico and several other countries (28). Severe leaf rust epidemics on susceptible durum wheat cultivars resulted in yield losses of up to $74 \%$ when infection occurred during an early phase of plant development (6). The deployment of resistant cultivars is an efficient way to control the disease, and the use of molecular markers offers a powerful tool to identify leaf rust resistance genes in durum wheat and determine their chromosomal location $(7,8)$. Publicly available linkage maps of common wheat ( $T$. aestivum), such as the International Triticeae Mapping Initiative (ITMI) population $(16,18,20,21,31)$, can greatly assist in the identification of genes also present in durum wheat $(7,8)$, because associated markers of unknown position in durum wheat can be mapped through the

Corresponding author: S. A. Herrera-Foessel E-mail: s.herrera@cgiar.org

Present address of S. A. Herrera-Foessel: CIMMYT, Apdo. Postal 6-641,06600, Mexico, DF.

Accepted for publication 20 August 2008.

doi:10.1094/PDIS-92-12-1650

(c) 2008 The American Phytopathological Society use of these common wheat populations, which are better defined compared with linkage maps of durum wheat. The ITMI linkage maps consist of more than 1,000 markers and are publicly available in GrainGenes (http://wheat.pw.usda.gov/GG2/ index.shtml).

Singh et al. (27) reported that only a few durum wheat cultivars from different countries were resistant to the Mexican $P$. triticina race $\mathrm{BBG} / \mathrm{BN}$. Although various studies on the genetic basis of leaf rust resistance in durum wheat have been conducted, the identification of effective resistance genes remains incomplete (9), and it is not clear whether the resistance is conferred by previously known $L r$ genes or uncharacterized genes. This information is important for the effective deployment of resistance sources and for the development of resistant cultivars. Of the known leaf rust resistance genes, $\operatorname{Lr} 3$ (7), $\operatorname{LrlO}$ (1), Lr14a (8), and Lr23 (19) were confirmed to be present in durum wheat. Genes $L r 3$ and $L r 14 a$ are effective against $P$. triticina race $\mathrm{BBG} / \mathrm{BN}$ as well as against races with similar avirulence and virulence patterns prevailing in several other durum wheatproducing countries (23). Virulence to Lr10 and $L r 23$ is frequent among $P$. triticina races collected from durum wheat $(10,23)$. In addition to these known genes, Lr53, which is effective against several
South African and Canadian P. triticina races, was recently transferred from $T$. turgidum subsp. dicoccoides to common wheat by Marais et al. (15). Hussein et al. (11) identified the chromosomal location of two novel adult-plant resistance genes, Lrac124 from durum wheat and Lrac104 from emmer wheat ( $T$. turgidum subsp. dicoccum), on $4 \mathrm{~A}$ and $6 \mathrm{~B}$, respectively, which are effective against several South African $P$. triticina races. The effectiveness of the genes identified by Marais et al. (15) and Hussein et al. (11) to P. triticina durum wheat races predominant in other countries needs further investigation. In addition, Herrera-Foessel et al. (7) identified an effective resistance gene, transferred to International Maize and Wheat Improvement Center (CIMMYT) durum germplasm from an Ethiopian landrace that is very closely linked in repulsion to Lr3 on chromosome 6BL and present in the CIMMYT durum wheat line 'Camayo.'

Herrera-Foessel et al. (9) identified a partially dominant leaf rust resistance gene in the Chilean cv. Guayacan INIA (24) and in the CIMMYT breeding line Guayacan 2 , which is a sister line with common pedigree 'Altar 84/Stint/Silver_45.' Presence of this gene is associated with immunity (or rare moderately resistant pustules) in the field to $P$. triticina race $\mathrm{BBG} / \mathrm{BN}$, and an infection type response of ' $; 1$ ' or ' $\mathrm{X}$ ' in seedlings and ' $; 1$ ' in adult plants in greenhouse tests (9). Herrera-Foessel et al. (9) developed and evaluated about $200 \mathrm{~F}_{2}$ plants and 98 individual $\mathrm{F}_{2}$-derived $\mathrm{F}_{3}$ progenies from crosses of susceptible Mexican cv. Atil C2000 with resistant parents Guayacan INIA and Guayacan 2. $\mathrm{F}_{2}$ populations from the intercross between the two resistant parents were also studied using the allelism test to confirm that the two sister lines were carrying the same leaf rust resistance gene.

The objective of this research was to identify the chromosomal location of the leaf rust resistance gene present in the Chilean durum wheat cv. Guayacan INIA and in the CIMMYT breeding line Guayacan 2 .

\section{MATERIALS AND METHODS}

Plant materials and leaf rust evaluations. The $98 \mathrm{~F}_{3}$ Atil $\mathrm{C} 2000 \times$ Guayacan INIA families were used in the present 
study for molecular characterization of the leaf rust resistance gene. The Atil C2000 × Guayacan INIA population was evaluated, together with the parents in a greenhouse test using the $P$. triticina race $\mathrm{BBG} / \mathrm{BN}$ (isolate name MEX01.13) to confirm the phenotypic responses previously obtained from the field evaluations (9). Approximately 30 plants per family were sown in trays and inoculated at the two-leaf stage by spraying urediniospores suspended in a light-mineral oil, Soltrol 170 (Phillips 66 Co., Bartlesville, OK). After $24 \mathrm{~h}$ of dew exposure, the plants were transferred to a greenhouse kept at 17 to $24^{\circ} \mathrm{C}$. At 10 days post inoculation, plants were evaluated for infection type responses according to a 0 to-4 scale (25). Plants with infection-type responses ' 3 ' and ' 4 ' were considered susceptible, whereas other infection-type responses were considered resistant. Depending on responses of plants within a family, each family was categorized as homozygous resistant (all plants resistant), homozygous susceptible (all plants susceptible), or segregating (plants originating from a heterozygous $\mathrm{F}_{2}$ plant). The $\chi^{2}$ test was used for comparing the observed distribution of homozygous resistant, homozygous susceptible, and segregating families of the Atil C2000 $\times$ Guayacan INIA population with the distribution expected for different numbers of genes.

Comparison of seedling infection type responses of tester lines with resistance genes located on chromosome arm 6BS. A greenhouse experiment was established to compare the infection type responses of Guayacan INIA and Guayacan 2 with tester lines carrying the seedling leaf rust resistance genes $\operatorname{Lr} 36$ and $L r 53$ known to be located on chromosome arm 6BS $(3,15)$. Both of these genes were in a common wheat background, Lr36 in a Manitou spring wheat (developed at the University of Saskatchewan, Saskatoon, Canada, tester E84018) (3) and Lr53 in a Chinese Spring background (tester 98M71) (14). The susceptible durum wheat parent Atil C2000 and the susceptible common wheat Thatcher were also included. Four $P$. triticina races, $\mathrm{BBG} / \mathrm{BN}$ (MEX01.13), $\mathrm{BBB} / \mathrm{BN}$ (MEX91.7B), NCJ/BN (MEX94.307A), and MCJ/SP (MEX94.1A), were used in the experiment. Race $\mathrm{BBB} / \mathrm{BN}$ was predominant in Mexican durum wheat fields before the establishment of $\mathrm{BBG} / \mathrm{BN}$ in 2001 (28). Races NCJ/BN and MCJ/SP $(26,33)$ were originally collected from Mexican common wheat fields. The nomenclature used for $P$. triticina races is based on Long and Kolmer (13), with some modifications (26). The avirulence/ virulence formulae for these races are given below.

BBG/BN:

Lr1,2a,2b,2c,3a,3bg,3ka,9,13,14a,15,16,17, $18,19,21,24,25,26,27+31,28,29,30,32,36 / 10$, $11,14 b, 20,23,33$;
$\mathrm{BBB} / \mathrm{BN}$ :

Lrl,2a,2b,2c,3a,3bg,3ka,9,11,13,14a,15,16,

$17,18,19,21,24,25,26,27+31,29,30,32,33$, $36 / 10,14 b, 20,23,28$;

$\mathrm{LCJ} / \mathrm{BN}$ :

Lr2a,2b,2c,3a,3bg,3ka,9,13,15,16,18,19,21, $24,25,27+31,29,30,32,33,36 / 1,10,11,14 a, 14 b$, 17,20,23,26,28;

$\mathrm{MCJ} / \mathrm{SP}$ :

Lr2a,2b,2c,3ka,9,16,19,21,24,25,28,29,30,

$32,33,36 / 1,3 a, 3 b g, 10,11,12,13,14 a, 14 b, 15$, $17,18,20,23,26,27+31$.

Three pots per genotype with eight seedlings (two-leaf stage) per pot were inoculated with each race. Plants were tested at low, intermediate, and high post-inoculation regimes with minimum and maximum temperatures of 12 to 21,16 to 28 , and 22 to $42^{\circ} \mathrm{C}$, respectively. Infection type responses were recorded 11 days after inoculation according to the 0-to-4 scale described by Roelfs et al. (25).

DNA extraction and bulked segregant analysis. Twenty plants from each $\mathrm{F}_{3}$ family of the Atil C2000 × Guayacan INIA population were grown in the greenhouse together with the parents. After 3 weeks, plants were harvested and leaf tissue lyophilized. The DNA extraction was carried out according to a cetyltrimethylammonium bromide (CTAB) procedure described in CIMMYT protocols (2). Molecular markers putatively linked to the resistance gene were identified by the bulked segregant analysis (BSA) approach described by Michelmore et al. (17). Equal amounts of DNA from 14 homozygous resistant families were pooled, and the same was done with 14 homozygous susceptible families. The resistant and susceptible bulks and DNA from the parents were screened for amplified fragment length polymorphisms (AFLPs). Once a polymorphism was identified, the same primer combination was used to screen each of the 28 families (14 homozygous resistant and 14 homozygous susceptible) separately. Only those polymorphisms associated with the resistance gene were then used for screening the entire population from the Atil C2000 × Guayacan INIA cross.

AFLP marker analysis. The AFLP technique was used according to Vos et al. (32) with some modifications (2). The DNA was digested with the two restriction enzymes, PstI and MseI. Double-stranded PstI and MseI adaptors were ligated to the restriction sites. A preamplification step was conducted using adaptor and restriction site-specific primers with an additional single nucleotide in the DNA fragment. The selective amplification step was then used with primers having the same sequence as the preamplification primers with two additional nucleotides. In total, 96 primer combinations of Pst $\mathrm{I} / \mathrm{Mse}$ I were used in the AFLP analysis. The AFLP bands were designated according to the nomenclature described by Herrera-Foes- sel et al. (7). Two primer combination sets were used. The first set of 48 primer combinations for the main amplification step consisted of four $P s t \mathrm{I}+N N N$ primers, $(P 33$, $P 36, P 37$, and P41) that were used together with $12 M s e \mathrm{I}+N N N$ primers $(M 47$, M48, M49, M50, M55, M56, M57, M58, M59, M60, M61, and M62). The second set of 48 primer combinations included four $P s t \mathrm{I}+N N N$ primers $(P 81, P 87, P 88$, and $P 89)$ that were used with $12 M s e I+N N N$ primers (M63, M64, M65, M66, M67, M68, M69, M70, M75, M76, M77, and M78). Each associated AFLP band was designated by the primer combination together with the size of the band in subscript. A 25-bp-sized marker which was run on the same acrylamide gel was used to determine the relative size of the AFLP band of interest. The main amplification product was separated on acrylamide gels under denaturing conditions, then transferred overnight onto Hybond nitrocellulose filters. A chemiluminescent procedure was used for detecting the bands according to published protocols (2). In this detection procedure, the PstI primers used in the main amplification step as well as the size marker were end labeled with digoxigenin (Sigma-Genosys Ltd., UK). The amplification fragments were visualized on X-ray films and consisted of approximately 50 bands per primer combination.

Linkage and statistical analysis. The AFLP bands that were associated with the leaf rust resistance gene in the Atil C2000 $\times$ Guayacan INIA population were mapped using two common wheat populations, the ITMI population ('Opata M85' × 'Synthetic W-7984' = 'Altar C84'/T. taushii CI 18 = WPI 219) described by Nelson et al. (21) and the 'Oligoculm' $\times$ 'Fukuho-komugi' population developed by Suenaga et al. (30). The ITMI population consists of 114 recombinant inbred lines (RILs), and publicly available segregation scores of more than 800 markers were used for the linkage analysis (http://wheat.pw.usda.gov/ GG2/index.shtml). The Oligoculm $\times \mathrm{Fu}-$ kuho-komugi population comprises 107 double haploids, and the linkage maps consisted of approximately 600 markers (30). Naturally, only those AFLP markers that were polymorphic in the common wheat parents could be mapped. MAPMAKER version 3.0 at minimum $3.0 \mathrm{log}$ of odds (LOD) score (12) was used for the linkage analyses. The $\chi^{2}$ test for goodnessof-fit was used to compare observed ratios of all markers in each population with expected ratios.

Simple sequence repeat analysis. When the chromosomal location of the AFLP markers associated with the leaf rust resistance gene was established to chromosome 6BS, several simple sequence repeat (SSR) markers (Xbarc76, Xbarc146, Xwmc104, Xwmc105, xwmc179, Xwmc182, Xwmc397, Хwmc398, Хwmc419, Хwmc473, Xwmc486, Хwmc487, Хwmc494, Хwmc737, 
Xgwm70, Xgwm88, Xgwm132, Xgwm191, Xgwm193, Xgwm361, Xgwm508, Xgwm518, Xgwm613, and Xgwm644), located on the short arm or centromeric region of the same chromosome according to Somers et al. (29), were tested on the durum parents Atil C2000 and Guayacan INIA. The two parents of the ITMI population were also included because they are known to be polymorphic for many of the SSR markers, and the estimated allele sizes of the ITMI parents are available from the GrainGenes database. When an SSR marker was polymorphic in the durum parents, the same marker was screened in 14 homozygous resistant and 14 homozygous susceptible families from the Atil C2000 × Guayacan INIA $F_{3}$ population to determine whether it was associated with the leaf rust resistance gene. If association was found, the marker was screened in the entire durum population. The amplification reaction was performed according to published protocols (2), and the polymerase chain reaction (PCR) program used depended on the optimal annealing temperature for each primer. The PCR products were separated on $3 \%$ agarose gels with two parts of SeaKem to three parts of MetaPhor agarose and, de- pending on the polymorphisms observed for each marker, $8 \%$ acrylamide $(29: 1)$ gels were also used. The amplification product was visualized on agarose gels with ethidium bromide or with silver staining for acrylamide gels (2).

\section{RESULTS AND DISCUSSION}

Characterization of leaf rust resistance in the durum wheat mapping population. In the greenhouse, Atil C2000 displayed an infection type response of ' $3+$ ' and Guayacan INIA ' 11 ', with the exception of one plant that had ' $\mathrm{X}$-'. The $\mathrm{F}_{3}$ families of Atil $\mathrm{C} 2000 \times$ Guayacan INIA were either susceptible, resistant, or segregating. Most resistant plants in the population had infection type ' $; 1$ ' but plants with ' 1 ' or '1-' were also found, and occasional plants displayed ' $\mathrm{X}$-' and ' $\mathrm{X}$ ' reactions. Phenotypic distribution of the 98 $\mathrm{F}_{3}$ families based on seedling tests was in accordance with earlier results from the field evaluation (9), except for 11 families. Of these 11 families, 10 were classified as segregating in the field evaluation; however, in the greenhouse test, only susceptible plants were found in each family and, therefore, the 10 families were reclassified

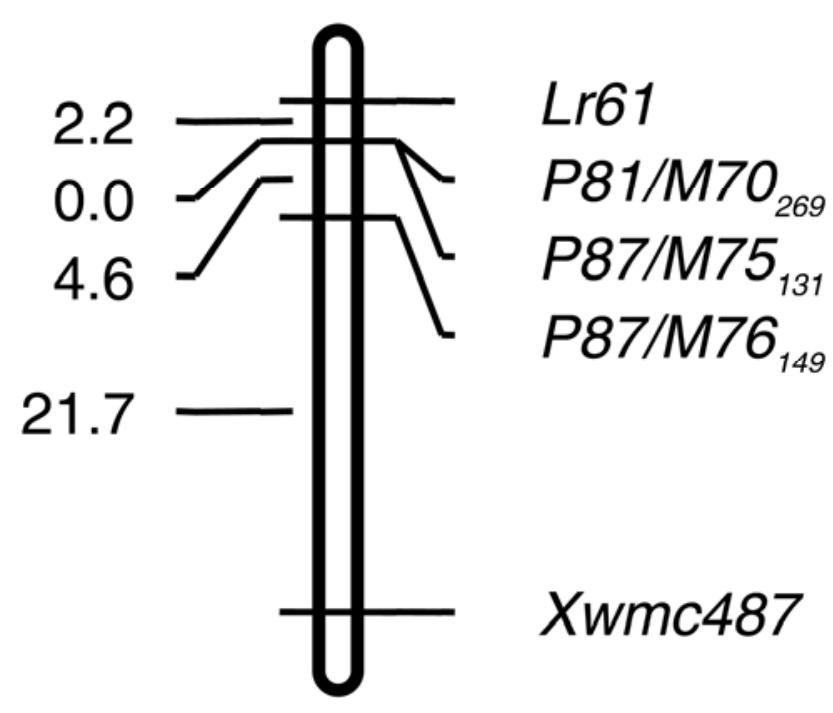

Fig. 1. Distance in centimorgans between amplified fragment length polymorphism markers and simple sequence repeat marker Xwmc487-6B linked to leaf rust resistance gene $\operatorname{Lr61}$ present in durum wheat Guayacan INIA using the phenotypic and molecular responses of $98 \mathrm{~F}_{3}$ lines from the Atil C2000 $\times$ Guayacan INIA cross.

Table 1. Presence of amplified fragment length polymorphism bands of markers $P 81 / M 70_{269}$, $P 87 / M 75_{131}$, and $P 87 / M 76_{149}$ linked in coupling with resistance to leaf rust in $98 \mathrm{~F}_{3}$ families from Atil C2000 $\times$ Guayacan INIA

\begin{tabular}{lccc}
\hline & \multicolumn{3}{c}{$\mathbf{F}_{\mathbf{3}}$ families (no.) with marker band present } \\
\cline { 2 - 4 } Marker & Homozygous susceptible & Segregating & Homozygous resistant \\
\hline$P 81 / M 70_{269}$ & $1^{\mathrm{a}}$ & 44 & 32 \\
$P 87 / M 75_{131}$ & $1^{\mathrm{b}}$ & $42^{\mathrm{c}}$ & 32 \\
$P 87 / M 76_{149}$ & $4^{\mathrm{d}}$ & $42^{\mathrm{c}}$ & $31^{\mathrm{e}}$ \\
\hline
\end{tabular}

a Marker band absent in 20 lines.

${ }^{\mathrm{b}}$ Maker band absent in 18 lines and no data available for 2 lines.

${ }^{c}$ No data available for 2 lines.

${ }^{\mathrm{d}}$ Marker band absent in 17 lines.

e No data for 1 line.

as homozygous susceptible. One family classified as homozygous resistant in the field segregated in the greenhouse study and was reclassified as segregating. The number of homozygous resistant, homozygous susceptible, and segregating families based on the greenhouse evaluations were 32,21 , and 45 , respectively. Herrera-Foessel et al. (9) earlier reported a $P$ value of 0.02 in the $\chi^{2}$ test when testing for a single-gene-based resistance using results from the field evaluations. The reclassification of these families based on the greenhouse test gave a better $P$ value of 0.19 for the expected distribution for a single gene. Misclassification in the field evaluation could have been due to late development of some segregating families, resulting in uneven disease ratings, or to the presence of slow-rusting resistance genes in the resistant parent that could have resulted in lower severities of some plants, giving the impression that the family was segregating.

Molecular mapping of the resistance gene. The BSA approach led to the identification of three AFLP markers associated with the leaf rust resistance gene present in the Atil C2000 $\times$ Guayacan INIA population (Fig. 1). The AFLP markers located nearest to the gene were $P 81 / M 7 O_{269}$ and $P 87 / M^{2} 5_{131}$ at a distance of 2.2 centimorgans (cM). The third AFLP marker, $P 87 / M 76_{149}$, was associated with the leaf rust resistance gene at a distance of 6.8 cM. All three markers were linked in coupling with the leaf rust resistance gene and present in Guayacan INIA but absent in Atil C2000. The observed ratios of the three AFLP markers were in accordance with the 3:1 ratio expected in the $\chi^{2}$ tests $(P=0.24$ to 0.41$)$. Presence of bands for each of the three AFLP markers and reaction category of $\mathrm{F}_{3}$ lines in the Atil $\mathrm{C} 2000$ $\times$ Guayacan INIA population are given in Table 1.

When these AFLP markers were tested in Opata M85, Synthetic W-7984, Oligoculm, and Fukuho-komugi (parents of the common wheat reference populations), only two of the three identified AFLP markers showed polymorphism. The AFLP marker $P 87 / M 76_{149}$ was polymorphic in Opata M85 and Synthetic W-7984 and, therefore, screened in the 114 RILs of the ITMI population. Linkage mapping with the segregation scores of $P 87 / M 7 \sigma_{149}$ together with genotypic data of more than 800 markers determined the location of these markers to chromosome 6BS. A small linkage group was obtained at the very end of the short arm (Fig. 2). The segregation of $P 87 / M 76_{149}$ was in accordance with the expected ratio of $1: 1(P=$ $0.26)$ in the ITMI population and located at a distance of $7.7 \mathrm{cM}$ from the nearest positioned marker, the restriction fragment length polymorphism (RFLP) marker $X b c d 342-6 B$, at $10.3 \mathrm{cM}$ from the SSR marker $X g w m 613-6 B$, and at $14.4 \mathrm{cM}$ from another RFLP marker, Xcdo476-6B. 
The AFLP marker $P 81 / M 70_{269}$ was polymorphic in Oligoculm and Fukuho-komugi parents of the second common wheat reference population. The segregation of $P 81 / M 70_{269}$ in the Oligoculm $\times$ Fukuhokomugi population conformed to the expected ratio of $1: 1$ in the $\chi^{2}$ test $(P=0.73)$. The linkage analysis of $P 81 / M 70_{269}$ in the Oligoculm $\times$ Fukuho-komugi population using genotypic data of more than 600 markers also determined the chromosomal location to the short arm of the same chromosome, 6BS (Fig. 3). This marker was closely associated, at $2.1 \mathrm{cM}$, with the RFLP marker XksuG8. The remaining markers in this rather large linkage group were positioned at distances of more than $12.6 \mathrm{cM}$ from $P 81 / M 70_{269}$. Hence, using two different common wheat linkage maps, we determined the chromosomal position of the leaf rust resistance gene in Guayacan INIA to the distal end of chromosome arm 6BS.

An attempt was made to find association of SSR markers located on the short arm or near the centromere of this chromosome with the leaf rust resistance gene in Guayacan INIA. Of the 24 SSR markers tested on the two parents Atil C2000 and Guayacan INIA, eight (Xbarc146, Xwmc104, Xwmc419, Xwmc179, Xwmc487, Xgwm88, $X g w m 191$, and Xgwm193) were polymorphic (i.e., $33 \%$ of the SSR markers). How- ever, only one of these markers, Xwmc487, succeeded in establishing an association with the leaf rust resistance gene. The segregation of this co-dominant marker, $X w m c 487$, in the durum population conformed to the expected ratio of 1:2:1 ( $P=$ $0.83)$; however, it was located at a rather large distance $(28.5 \mathrm{cM})$ from the Guayacan INIA leaf rust resistance gene (Fig. 1).

Comparison of infection types displayed by common wheat tester lines with resistance genes located on chromosome arm 6BS. The infection type responses of the two sister lines Guayacan INIA and Guayacan 2 were similar across different races and temperatures (Table 2). Atil C2000 displayed a susceptible infection type only with race $\mathrm{BBG} / \mathrm{BN}$. The higher infection type response with race $\mathrm{BBB} / \mathrm{BN}$ displayed by Guayacan INIA and Guayacan 2 compared with Atil C2000 may indicate that Guayacan INIA and Guayacan 2 most likely do not carry the resistance gene present in Atil C2000 that became ineffective with the appearance of race $\mathrm{BBG} / \mathrm{BN}$ in northwestern Mexico. The intermediate infection types of Guayacan INIA and Guayacan 2 were different from the very low responses of the Lr53carrying common wheat line, indicating that the gene identified in durum wheat is different from the leaf rust resistance gene of $T$. turgidum subsp. dicoccoides origin

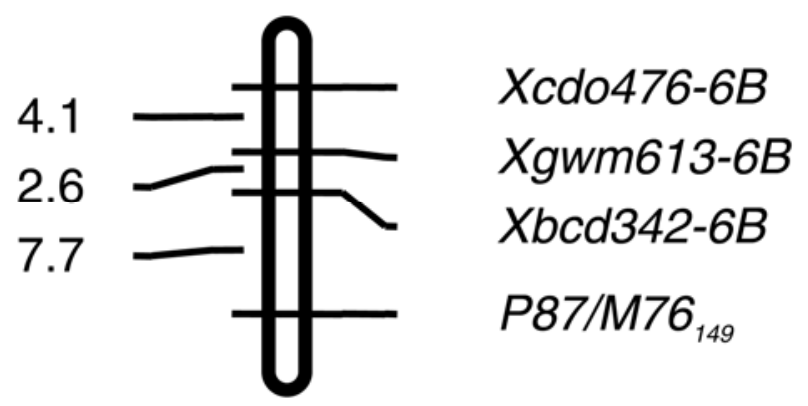

Fig. 2. Linkage group of markers located on chromosome arm 6BS based on the International Triticeae Mapping Initiative (ITMI) population including the amplified fragment length polymorphism marker $\left(P 87 / M 76_{149}\right)$ associated with the resistance gene present in durum wheat Guayacan INIA. Distances are displayed in centimorgans.

(15). The common wheat line carrying Lr36, a gene originally transferred from $T$. speltoides (3), also showed intermediate infection type responses but a characterizing feature of this line was that, across the four races, the infection type responses became lower with higher temperature (i.e., plants became more resistant at higher temperatures). This tendency was not observed with the resistance gene present in the two durum wheat lines.

Hart et al. (5) described the location of several genes in wheat, including Lr36 on the short arm of chromosome 6B; however, the association of these genes with other markers in the same chromosome was not provided. In the genetic map of group 6 developed by Erayman et al. (4) that shows

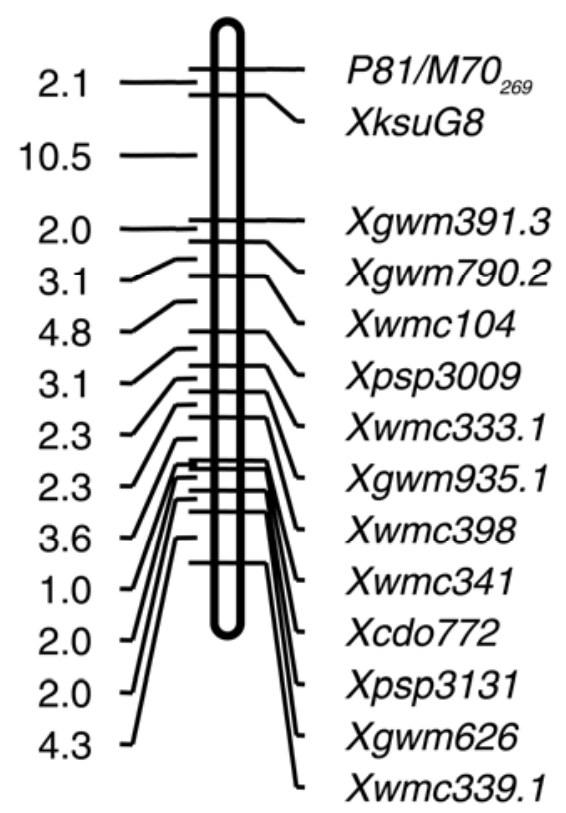

Fig. 3. Linkage group of markers located on chromosome 6BS based on the Fukuho-Komugi $\times$ Oligoculm population, including the amplified fragment length polymorphism marker $\left(P 81 / M 70_{269}\right)$ associated with the leaf rust resistance gene present in durum wheat Guayacan INIA. Distances are given in centimorgans.

Table 2. Seedling (two-leaf stage) infection-type responses for durum wheats Atil C2000, Guayacan INIA, and Guayacan 2 and common wheat testers carrying resistance genes Lr36 and Lr53 along with the susceptible control Thatcher when inoculated with Puccinia triticina races BBG/BN, BBB/BN, NCJ/BN, and $\mathrm{MCJ} / \mathrm{SP}$, and incubated at three temperature regimes ${ }^{\mathrm{a}}$

\begin{tabular}{|c|c|c|c|c|c|c|c|c|c|c|c|c|}
\hline \multirow[b]{3}{*}{ Genotype } & \multicolumn{12}{|c|}{$P$. triticina race and infection-type responses ${ }^{b}$} \\
\hline & \multicolumn{3}{|c|}{ BBG/BN } & \multicolumn{3}{|c|}{$\mathbf{B B B} / \mathbf{B N}$} & \multicolumn{3}{|c|}{ NCJ/BN } & \multicolumn{3}{|c|}{ MCJ/SP } \\
\hline & Low $T$ & Int $\mathbf{T}$ & High T & Low $\mathrm{T}$ & Int $\mathrm{T}$ & High T & Low $\mathbf{T}$ & Int $\mathrm{T}$ & High T & Low T & Int $\mathbf{T}$ & High T \\
\hline Atil C2000 & 4 & 4 & $3+$ & ;12 & $; 12$ & ;12- & 12 & 12 & $3 \mathrm{C} 3+$ & ;12- & ;1- & ;12 \\
\hline Guayacan 2 & ;11+ & $; 1$ & 12 & $\mathrm{XX}+$ & $\mathrm{X}+$ & $\mathrm{XX}+$ & 12 & 12 & ;12- & 12 & ;12 & $1+3 C$ \\
\hline Guayacan INIA & $; 11+$ & $; 1$ & 12 & $\mathrm{XX}+$ & $\mathrm{X}+$ & $\mathrm{XX}+$ & 12 & 12 & ;12- & 12 & $; 12$ & $1+3 \mathrm{C}$ \\
\hline 98M71 (Lr53) & ;1- & 0 & $; 1$ & 0 & 0 & $; 1-$ & $; 1-$ & ; & ; & ; & ; & ; \\
\hline E84018 (Lr36) & $1+3 C$ & $1+$ & $; 1$ & $1+3 C$ & $X-$ & 1 & $X$ & $X-$ & $; 1-$ & $3 \mathrm{C} 3$ & $3 \mathrm{C} 3$ & $X$ \\
\hline Thatcher & $3+$ & 4 & $3+$ & $3+$ & 4 & 4 & 4 & 4 & 4 & 4 & 4 & 4 \\
\hline
\end{tabular}

a Temperature regimes: Low $\mathrm{T}$, Int $\mathrm{T}$, and High $\mathrm{T}=$ minimum and maximum temperatures of 12 to 21,16 to 28 , and 22 to $42^{\circ} \mathrm{C}$, respectively.

b Infection-types are based on a 0-to-4 scale (27), where ' 0 ' = no uredinia or other macroscopic signs of infection; '; = no uredinia, but hypersensitive necrotic or chlorotic flecks of varying sizes present; ' 1 ' = small uredinia surrounded by necrosis; ' 2 ' = small to medium uredinia surrounded by green islands; ' $\mathrm{X}$ ' = random distribution of variable-sized uredinia on a single leaf with a pure culture; ' 3 ' and ' 4 ' $=$ medium and large uredinia, respectively, without chlorosis or necrosis; ' + ' and '- or =' = uredinia somewhat larger and smaller, respectively, than normal for infection-type; and 'C' = more chlorosis than normal for the infection-type. More than one designation represents a range of infection types. 
distribution of genes and recombination distances on wheat chromosomes, Lr36 is located more than $20 \mathrm{cM}$ proximal to the centromere compared with the RFLP markers $X k s u G 8$ (Fig. 3), Xbcd342-6B, and $X c d o 476$ (Fig. 2). The same RFLP markers were associated with the two AFLP markers $P 87 / M 76_{149}$ and $P 81 / M 70_{269}$, which are linked to the leaf rust resistance gene in Guayacan INIA according to the common wheat populations used in our study. Furthermore, markers XksuH4 and Xtam60, located in the same region as $\operatorname{Lr} 36$ according to Erayman et al. (4), are at least 23 $\mathrm{cM}$ proximal to the centromere compared with markers $X b c d 342-6 B$ and $X c d o 476$ (Fig. 2) in the ITMI genetic map developed by Marino et al. (16). Moreover, no association was established between markers $\mathrm{XksuH4}$ and Xtam60 and AFLP markers $P 87 / M 76_{149}$ and $P 87 / M 76_{150}$, which are linked to the leaf rust resistance gene in Guayacan INIA (Fig. 2) according to our linkage analysis using the ITMI population. $\operatorname{Lr} 53$ is also located more proximal to the centromere of chromosome $6 \mathrm{~B}$ according to unpublished data (C. Wellings, personal communication). Hence, phenotypic comparison with the leaf rust resistance genes present on the same chromosome arm and the more proximal chromosomal location of $\operatorname{Lr} 36$ and $\operatorname{Lr} 53$ on 6BS indicate that the leaf rust resistance gene identified in Guayacan INIA is a noncatalogued gene and, hence, designated as Lr61. Additional information on the genetic distance between these genes can be achieved by transferring Lr61 into common wheat and then crossing with respective tester lines carrying $\operatorname{Lr} 36$ and $\operatorname{Lr} 53$.

The original source of the leaf rust resistance gene in the sister lines Guayacan INIA and Guayacan 2 is unknown. The gene could have originated from either of two durum wheats, Stint or Silvertail_45, because Altar C84 is susceptible to race $\mathrm{BBG} / \mathrm{BN}$. For its further use in agriculture, we recommend this gene to be pyramided with other effective $L r$ genes. As also pointed out by Nocente et al. (22), the pyramiding of resistance genes in new cultivars can only be regarded to be effective against the pathogen if virulence frequencies for the combined genes are very low. Virulence to Lr61 gene is so far not known.

\section{ACKNOWLEDGMENTS}

We thank the Swedish Agency for Research Cooperation with Developing Countries (SIDASAREC), CONACYT Project 12163, COFUPRO Project 26-2007-1132, the Department of Forest Mycology and Pathology at the Swedish University of Agricultural Sciences, and CIMMYT for financial support; and A. McNab for technical editing.

\section{LITERATURE CITED}

1. Aguilar-Rincon, V. H., Singh, R. P., Gonzalez, F. C., and Huerta-Espino, J. 2001. Genes de resistencia a la roya de la hoja en un trigo sinté- tico hexaploide. Rev. Fitotec. Mex. 24:161169

2. Anonymous. 2005. Laboratory Protocols: CIMMYT Applied Molecular Genetics Laboratory, Third Edition. CIMMYT, Mexico, DF.

3. Dvorak, J., and Knott, D. R. 1990. Location of a Triticum speltoides chromosome segment conferring resistance to leaf rust in Triticum aestivum. Genome 33:892-897.

4. Erayman, M., Sandhu, D., Sidhu, D., Dilbirligi, M., Baenzinger, P. S., and Gill, K. S. 2004. Demarcating the gene-rich regions of the wheat genome. Nucleic Acids Res. 32:35463565 .

5. Hart, G. E., Gale, M. D., and McIntosh, R. A. 1993. Linkage maps of Triticum aestivum (hexaploid wheat, $2 \mathrm{n}=42$, genomes $\mathrm{A}, \mathrm{B}$, and D) and T. tauschii $(2 \mathrm{n}=14$, genome D). Genetic maps: locus maps of complex genomes. Pages 204-219 in: Genetic Maps, Vol. 6. S. J. O'Brian, ed. Cold Spring Harbor Laboratory Press, Cold Spring Harbor, NY.

6. Herrera-Foessel, S. A., Singh, R. P., HuertaEspino, J. Crossa, J., Yuen J., and Djurle A. 2006. Effect of leaf rust on grain yield and yield traits of durum wheats with race-specific and slow rusting resistance to leaf rust. Plant Dis. 90:1065-1072.

7. Herrera-Foessel, S. A. Singh, R. P., HuertaEspino, J., William M., Rosewarne, G., Djurle, A., and Yuen, J. 2007. Identification and mapping of $L r 3$ and a linked leaf rust resistance gene in durum wheat. Crop Sci. 47:1459-1466.

8. Herrera-Foessel, S. A. Singh, R. P., HuertaEspino, J., William M., Rosewarne, G., Djurle, A., and Yuen, J. 2008. Identification and molecular characterization of $L r 14 a$ in durum wheat. Plant Dis. 92:469-473.

9. Herrera-Foessel, S. A., Singh, R. P., HuertaEspino, J. Yuen, J., and Djurle, A. 2005. New genes for leaf rust resistance in CIMMYT durum wheats. Plant Dis. 89:809-814.

10. Huerta-Espino, J., and Roelfs, A. P. 1992. Leaf rust on durum wheats. Vortr. Pflanzenzuchtg. 24:100-102.

11. Hussein, S., Spies, J. J., Pretorius, Z. A., and Labuschagne M. T. 2005. Chromosome locations of leaf rust resistance genes in selected tetraploid wheat through substitution lines. Euphytica 141:209-216.

12. Lander, E., Green, P., Abrahamson, J., Barlow, A., Daley, M., Lincoln, S., and Newburg, L. 1987. MAPMAKER: an interactive computer package for constructing primary genetic linkage maps of experimental and natural populations. Genomics 1:174-181.

13. Long, D. L., and Kolmer, J. A. 1989. A North American system of nomenclature for Puccinia recondita $\mathrm{f}$. $\mathrm{sp}$. tritici. Phytopathology 79:525-529.

14. Marais, G. F., Pretorius, Z. A., Marais, A. S., and Wellings, C. R. 2003. Transfer of rust resistance genes from Triticum species to common wheat. S. Afr. J. Plant. Soil 20:193-198.

15. Marais, G. F., Pretorius, Z. A., Wellings, C. R., McCallum, B., and Marais, A. S. 2005. Leaf rust and stripe rust resistance genes transferred to common wheat from Triticum dicoccoides. Euphytica 143:115-123.

16. Marino, C. L., Nelson, J. C., Lu, Y. H., Sorrells, M. E., Leroy, P., Tuleen, N. A., Lopes, C. R., and Hart, G. E. 1996. Molecular genetic maps of the group 6 chromosomes of hexaploid wheat (Triticum aestivum L. em. Thell). Genome 39:359-366.

17. Michelmore, R. W., Paran, I., and Kesseli, V. 1991. Identification of markers linked to disease-resistance genes by bulked segregant analysis: a rapid method to detect markers in specific genomic regions by using segregating populations. Proc. Natl. Acad. Sci. USA
88:9828-9832.

18. Nelson, J. C., Sorrells, M. E., Van Deynze, A E., Lu, Y. H., Atkinson, M., Bernard, M. Leroy, P., Faris, J. D., and Anderson, J. A. 1995. Molecular mapping of wheat. Major genes, and rearrangements in homoeologous groups 4, 5, and 7. Genetics 141:721-731.

19. Nelson, J. C., Singh, R. P., Autrique, J. E., and Sorrells, M. E. 1997. Mapping genes conferring and suppressing leaf rust resistance in wheat. Crop Sci. 37:1928-1935.

20. Nelson, J. C., Van Deynze, A. E., Autrique, E., Sorrells, M. E., Lu, Y. H., Merlino, M., Atkinson, M., and Leroy, P. 1995. Molecular mapping of wheat. Homoeologous group 2. Genome 38:516-524.

21. Nelson, J. C., Van Deynze, A. E., Autrique, E., Sorrells, M. E., Lu, Y. H., Negre, S., Bernard, M., and Leroy, P. 1995. Molecular mapping of wheat. Homoeologous group 3. Genome 38:525-533.

22. Nocente, F., Gazza, L., and Pasquini, M. 2007. Evaluation of leaf rust resistance genes $\mathrm{Lrl}$, $\operatorname{Lr} 9, \operatorname{Lr} 24, \operatorname{Lr} 47$ and their introgression into common wheat cultivars by marker-assisted selection. Euphytica 155:329-336.

23. Ordóñez, M. E., and Kolmer, J. A. 2007. Virulence phenotypes of a worldwide collection of Puccinia triticina from durum wheat. Phytopathology 97:344-351.

24. Ramirez-A, I., Cortazar, S. R., Hacke, E. E., Granger, Z. D., and Zerene Z. M. 1997. Guayacan INIA, variedad de trigo candeal Triticum turgidum var. durum para la zona central de Chile. Agric. Téc. 57:209-211.

25. Roelfs, A. P., Singh, R. P., and Saari, E. E. 1992. Rust Diseases of Wheat: Concepts and Methods of Disease Management. CIMMYT, Mexico, DF.

26. Singh, R. P. 1991. Pathogenicity variations of Puccinia recondita f. sp. tritici and $P$. graminis f. sp. tritici in wheat-growing areas of Mexico during 1988 and 1989. Plant Dis. 75:790-794.

27. Singh, R. P., Huerta-Espino, J., Fuentes, G., Duvellier, E., Gilchrist, L., Henry, M., and Nicol, J. M. 2005. Resistance to diseases. Pages 291-328 in: Durum Wheat Breeding: Current Approaches and Future Strategies, Vol. 1. C. Royo, M. Miloudi, and N. di Fonzo, eds. Food Product Press, Binghamton, NY.

28. Singh, R. P., Huerta-Espino, J., Pfeiffer, W., and Figueroa-Lopez, P. 2004. Occurrence and impact of a new leaf rust race on durum wheat in north-western Mexico from 2001 to 2003. Plant Dis. 88:703-708.

29. Somers, D. J., Isaac, P., and Edwards, K. 2004. A high-density microsatellite consensus map for bread wheat (Triticum aestivum L.). Theor. Appl. Genet. 109:1105-1114.

30. Suenaga, K., Khairallah, M., William, H. M. and Hoisington, D. A. 2005. A new intervarietal linkage map and its application for quantitative trait locus analysis of "gigas" features in bread wheat. Genome 48:65-75.

31. Van Deynze, A. E., Dubkovsky, J., Gill, K. S., Nelson, J. C., Sorrells, M. E., Dvorak, J., Gill, B. S., Lagudah, E. S., McCouch, S. R., and Appels, R. 1995. Molecular-genetic maps for group 1 chromosomes of Triticeae species and their relation to chromosomes in rice and oat. Genome 38:45-59.

32. Vos, P., Hogers, R., Bleeker, M., Reijans, M. Van de Lee, T., Hornes, M., Frijters, A., Pot, J. Peleman, J., Kuiper, M., and Zabeau, M. 1995. AFLP: a new technique for DNA fingerprinting. Nucleic Acid Res. 23:4407-4414.

33. William, H. M., Singh, R. P., Huerta-Espino, J., Palacios, G., and Suenaga, K. 2006. Characterization of genetic loci conferring adult plant resistance to leaf rust and stripe rust in spring wheat. Genome 49:977-990. 